\title{
Conditionality Measures within the Euro Area Crisis: A Challenge to the Democratic Principle?
}

\author{
Antonia Baraggia*
}

\begin{abstract}
The crisis of the Eurozone and the risk of default for countries like Greece, Ireland and Portugal has led to the intervention of international and supranational institutions like the International Monetary Fund, the European Central Bank and the European Commission, which provided bailouts under a strict programme of conditionality measures to be implemented by the borrowing countries. The first part of the article explores the nature of conditionality measures and their impact on democratic governance within the European Union legal framework. The second part of the article considers the challenges posed by conditionality specifically to the European Union legal framework-including human rights protection and the democratic principle-both at the European Union and at national levels. The third part deals with the role of the national supreme courts in judging the legitimacy of such interventions, acting as watchdogs with respect to the democratic principle but, at the same time, creating a 'short circuit' of legitimation regarding decisions made by national governments (even if conditional).
\end{abstract}

\section{Keywords}

Conditionality, Memorandum of Understanding, European Stability Mechanism, Euro Crisis, Democracy

\section{Introduction}

Six years on from the eruption of the economic crisis within the European Union (EU) - in spite of its aftershock and the ongoing economic challenges endured by some Member States, as recent events in Greece have highlighted-it is now possible to begin to look with a detached gaze at the systemic effect of the crisis on the EU's legal space. One of the most evident effects of the economic crisis is that it has turned into a sort of existential crisis for the EU as a whole. The economic emergency unveiled the limits of the EU project, and it heightened the still-unsolved issues of its governance and of its democratic deficit, threatening the legitimacy of the integration process. However,

* Research Fellow in Constitutional Law at the State University of Milan, Department of National and Supranational Public Law (Italy). The author is grateful to Lorenza Violini, Marilena Gennusa and Andrea Rovagnati for their insightful observations and valuable suggestions. 
it also appeared clear that the future of the Member States could not be drawn outside the boundaries of the EU space. The interdependency of the Member States' economies, societies, and institutions has emerged as an incontrovertible fact of the EU space. Christian Joerges observed that European societies now sense that 'they are not or are no longer in a position to ensure responses to their concerns autonomously but instead depend on transnational co-operation. ${ }^{1}$

Here, however, lies a sort of paradox. Joseph Weiler argued:

[E]veryone knows that a solution has to be European, within a European framework. And yet, it has become self-evident that crafting a European solution has become so difficult that the institutions and the European [Union]'s decision-making process do not seem to be engaging satisfactorily and effectively with the crisis, even when employing intergovernmental methodology; and that it is the governments, national leaders of a small club, who seem to be calling the shots. The problem is European, but Europe as such is finding it difficult to craft the remedies. ${ }^{2}$

In fact, the response of the Member States to the crisis has been a substantial use of international law when establishing economic mechanisms in order to sustain the economies of the Member States in difficulties, and, as it will be shown, this decision has been made even outside of the framework of the EU treaties.

This new economic governance drafted chiefly through international law has represented a challenge to the democratic principle - to the principle of accountability and the protection of human rights both at the EU and national levels. The emblematic instruments that have characterised the modus operandi of the Member States outside the EU legal framework are 'conditionality measures', legitimacy and legality of which is debated among scholars, since they influence and bind what, by definition, should be unbound: the States' sovereignty. Moreover, it has been argued that conditionality, as prescribed in a Memorandum of Understanding (MoU), 'amounts to a sell-out of the political autonomy and responsibility of democratically legitimate institutions, an exchange of obedience for money. ${ }^{3}$ Starting from this point, the first part of the present paper explores the nature of conditionality measures and their impact on democratic governance within the EU legal framework. This is analysed through a review of the early mechanisms adopted to tackle the Eurozone crisis-the European Financial Stability Facility (EFSF) and the European Financial Stabilisation Mechanism (EFSM)

1 Christian Joerges, 'Three Transformations of Europe and the Search for a Way Out of its Crisis' in Christian Joerges and Carolina Glinski (eds), The European Crisis and the Transformation of Transnational Governance: Authoritarian Managerialism Versus Democratic Governance (Hart Publishing 2014) 32.

2 Joseph Weiler, 'Europe in Crisis-On "Political Messianism", "Legitimacy" and the "Rule of Law" [2012] Singapore JLS 248, 249.

3 Joerges (n 1) 34-35.

4 Consolidated Version of the European Financial Stability Facility Framework Agreement (adopted 7 June 2010, entered into force 18 October 2011) <http://www.efsf.europa.eu/attachments/20111019_efsf_ framework_agreement_en.pdf> accessed 11 November 2015; Regulation (EU) 407/2010 of the Council of 11 May 2010 establishing a European Financial Stabilisation Mechanism [2010] OJ L118/1. 
and their problematic 'constitutionalisation' with the adoption of the European Stability Mechanism (ESM), ${ }^{5}$ through the amendment of article 136 of the Treaty on the Functioning of the European Union (TFEU $)^{6}$ and the case law of the Court of Justice of the European Union (CJEU). ${ }^{7}$

The second part of the paper considers the challenges posed by conditionality specifically to the EU legal framework-to human rights protection and to the democratic principle-both at the EU and national levels. The third part reviews the reactions of the national institutions to such an intrusive exercise of power. In particular, I debate the role of the national supreme courts in judging the legitimacy of such interventions, acting as watchdogs with respect to the democratic principle but, at the same time, creating a 'short circuit' of legitimation regarding decisions made by national governments (even if conditional).

\section{Emergence of conditionality as a leitmotiv of EU financial assistance}

Until 2010 - when the initial bilateral loans were negotiated and the first mechanisms were created in order to tackle the Greek crisis-the word 'conditionality' was, from an EU perspective, associated with the requirement of meeting certain conditions by candidate Member States in order that they might enter the Union. ${ }^{8}$ Alternatively, 'economic conditionality' specifically referred to the policy of international financial institutions (ie, the International Monetary Fund (IMF)) of providing loans and financial aid to developing countries under a strict set of macroeconomic conditions. ${ }^{9}$ The EU participates in financial aid provision to non-Member States through its 'Macro-Financial Assistance to Non-EU Countries' programme, a complement to IMF financing that has provided, since 1990, financial support to partner countries experiencing a balance of payments crisis. ${ }^{10}$ In addition, article 143 TFEU provided the possibility of financial assistance to Member States facing difficulties in their balance of payments.

However, when the Greek crisis erupted in 2010, the EU did not have any instrument or procedure with which to tackle such a crisis in a Eurozone state. Therefore, based on a sort of 'legal experimentalism,', ${ }^{11}$ we witnessed the 'translation' of such policies from

5 Consolidated Version of the Treaty establishing the European Stability Mechanism (adopted 2 February 2012, entered into force 27 September 2012) (ESM Treaty) <http://esm.europa.eu/about/legal-documents/ ESM\%20Treaty.htm> accessed 11 November 2015.

6 Consolidated Version of the Treaty on the Functioning of the European Union [2012] OJ C326/47 (TFEU).

7 Case C-370/12 Pringle v Government of Ireland, Ireland and the Attorney General [2012] EU:C:2012:756.

8 See Marise Cremona, Accession to the European Union: Membership Conditionality and Accession Criteria' (2001) 25 Polish YB Intl L 219; Cesare Pinelli, 'Conditionality and Enlargement in Light of EU Constitutional Developments' (2004) 10 ELJ 354.

9 Axel Dreher, 'IMF Conditionality: Theory and Evidence' (2009) 141 Public Choice 233.

10 See European Commission, 'Macro-Financial Assistance to non-EU Countries' (2015) <http://ec.europa. eu/economy_finance/eu_borrower/macro-financial_assistance/index_en.htm > accessed 12 November 2015.

11 Kaarlo Tuori and Klaus Tuori, The Eurozone Crisis: A Constitutional Analysis (CUP 2014) 90. 
within the context of the relations among Member States of the Economic and Monetary Union (EMU). ${ }^{12}$ The story is well known: in May 2010, the Eurogroup signed a Draft Statement to activate, further to a request from the Greek government, stability support to Greece via bilateral loans centrally pooled by the European Commission. ${ }^{13}$ From the start, the Statement prescribed a regime of strong conditionality,

on the basis of a programme which has been negotiated with the Greek authorities by the Commission and the IMF, in liaison with the [European Central Bank (ECB)]. The programme has been approved by the Greek Council of Ministers on 2 May and endorsed by the Eurogroup on the basis of a Commission and ECB assessment. ${ }^{14}$

These elements of conditionality were further detailed in a MoU signed by the Greek government and the European Commission on behalf of the euro-area Member States. ${ }^{15}$

Following this first ad hoc intervention, enacted by means of intergovernmental agreements, two temporary funds were settled in order to assure the financial stability of the Eurozone as a whole: the EFSM and the EFSF. Aside from the differences between the two instruments (the former was an emergency funding programme, established under the provision of article 122(2) TFEU; the latter was a limited liability company under Luxembourg law), a common feature of the interventions was the provision of a conditionality regime, settled in the MoU that the Commission would sign with the beneficiary Member State.

Conditionality is even at the core of the ESM, an intergovernmental organisation under public international law that was first introduced by the European Council in 2010 (but that only entered into force in September 2012) as a permanent financial assistance programme to replace the temporary EFSF and EFSM funds. Article 3 of the Consolidated Version of the Treaty establishing the European Stability Mechanism (ESM Treaty) affirms that the purpose of the ESM 'shall be to mobilise and provide stability support under strict conditionality' in favour of ESM members that experience or are threatened by severe financial problems-but it also points out that conditionality should be appropriate to the financial assistance instrument chosen. Moreover, article 12 of the ESM Treaty underlines that conditionality 'may range from a macro-economic adjustment programme to continuous respect of pre-established eligibility conditions.' In article 13, the European Commission is entrusted, in liaison with the ECB and, wherever possible, with the IMF, with the task of negotiating (and signing) a MoU with the assisted Member State, and therein detailing the conditionality attached to the financial assistance facility.

12 See European Commission, 'Economic and Monetary Union' (2015) <http://ec.europa.eu/economy_ finance/euro/emu/index_en.htm> accessed 12 November 2015.

13 Eurogroup, 'Statement by the Eurogroup-Draft' (2 May 2010) <http://www.consilium.europa.eu/uedocs/ cmsUpload/100502-\%20Eurogroup_statement.pdf> accessed 11 September 2015.

14 ibid.

15 Greece, 'Memorandum of Understanding on Specific Economic Policy Conditionality' (3 May 2010) <http://ec.europa.eu/economy_finance/publications/occasional_paper/2010/pdf/ocp61_en.pdf> accessed 12 November 2015. 
Conditionality emerges, from this sketch briefly drafted, as a leitmotiv of the different instruments adopted by the Member States, the European Commission and the IMF to face the debt crisis and to safeguard the financial stability of the euro-area. However, the legitimacy and legality of such measures, and of the procedures through which they have been adopted, are highly contested. From a substantive point of view, as asserted by Joerges, conditionality as prescribed in a MoU 'amounts to a sell-out of the political autonomy and responsibility of democratically legitimate institutions, an exchange of obedience for money. ${ }^{16}$ From the procedural perspective, these measures have been adopted outside the legal framework of the Treaties by intergovernmental agreements under which compliance with the 'no bailout' clause of article 125 TFEU is questionable.

\section{3 'Constitutionalisation' of strict conditionality}

The eruption of the debt crisis caught the EU institutions completely unprepared, and they thus adopted an experimental approach and endeavoured to tailor its institutional instruments to the exceptional circumstances determined by the crisis. When the first programme for Greece and the EFSF were put in place, the legal basis was found in article 122(2) TFEU, according to which:

Where a Member State is in difficulties or is seriously threatened with severe difficulties caused by natural disasters or exceptional occurrences beyond its control, the Council, on a proposal from the Commission, may grant, under certain conditions, Union financial assistance to the Member State concerned.

However, even this interpretation appeared ambiguous. For example, it might be argued that 'Greece and Ireland were not facing exceptional occurrences beyond their control (as the text of Art 122 requires), since their governments had contributed to create the sovereign debt crises which they were facing. ${ }^{17}$

Further, the question of the legal basis of a financial assistance instrument arose following the proposal to establish the ESM as a permanent mechanism, in the light of which a revision of the Treaty was perceived as inevitable in order to resolve the legal uncertainties raised by the EFSM and the EFSF. The decision to start the revision procedure was taken during the same European Council of 28-29 October 2010 in which the creation of a permanent mechanism (ie, the ESM) was discussed. The amendment of article 136 TFEU was then adopted by Decision $2011 / 199,{ }^{18}$ according to the simplified revision procedure in article 48(6) TEU. Specifically, article 136(3) TFEU states that:

16 Joerges (n 1 ) 34.

17 Bruno de Witte, 'The European Treaty Amendment for the Creation of a Financial Stability Mechanism' (2011) 6 Eur Policy Analysis <www.sieps.se/sites/default/files/2011_6epa.pdf> accessed 8 July 2015.

18 Decision (EU) 2011/199 of the European Council of 25 March 2011 amending Article 136 of the Treaty on the Functioning of the European Union with regard to a Stability Mechanism for Member States whose Currency is the Euro [2011] OJ L91/1. 
The Member States whose currency is the euro may establish a stability mechanism to be activated if indispensable to safeguard the stability of the euro area as a whole. The granting of any required financial assistance under the mechanism will be made subject to strict conditionality. ${ }^{19}$

Thus, strict conditionality appears as a fundamental feature for the concession of financial assistance provided by a permanent crisis resolution mechanism settled in light of article 136 TFEU.

The same process of the constitutionalisation of strict conditionality was undertaken by the Court of Justice in its Pringle decision, in which the Court, stating the compatibility of the ESM with the Treaties and upholding the legitimacy of the revision of article 136, recognised strict conditionality as a requirement for financial assistance. ${ }^{20}$ The Court also stated that strict conditionality works as a guarantee that the mechanism will operate in a way that will comply with European Union law. ${ }^{21}$ In other words, the Court recognised that:

the purpose of the strict conditionality to which all stability support provided by the ESM is subject is to ensure that the ESM and the recipient Member States comply with measures adopted by the Union in particular in the area of the coordination of Member States' economic policies, those measures being designed, inter alia, to ensure that the Member States pursue a sound budgetary policy. ${ }^{22}$

According to this reasoning, conditionality is included in order to induce the beneficiary Member State to prudent fiscal policy, pursuing 'the very same objectives which the no bailout clause is expected, but has not managed, to achieve. ${ }^{23}$

Finally, yet importantly, the process of the institutionalisation of conditionality has been concluded with Regulation 472/2013, establishing 'a single EU framework for conditional sovereign lending common for all form of financial assistance. ${ }^{24}$

However, while strict conditionality may have attained constitutional status within the EU legal framework (ie, through CJEU case law and the amendment of article 136 TFEU), substantive doubts remain regarding its compatibility with principles such as democracy, accountability and sovereignty.

19 Art 136(3) TFEU (emphasis added).

20 Case C-370/12 Pringle (n 7) para 72.

21 ibid.

22 ibid para 143

23 Tuori and Tuori (n 11) 131. In this way, the CJEU also affirmed the compatibility of the ESM with the no bailout clause of art 125 TFEU.

24 Michael Ioannidis, 'EU Financial Assistance Conditionality After Two Pack' (2014) 7 ZaöRV 61, 64; Regulation (EU) 472/2013 of the European Parliament and of the Council of 21 May 2013 on the strengthening of economic and budgetary surveillance of Member States in the euro area experiencing or threatened with serious difficulties with respect to their financial stability [2013] OJ L140/1. 


\section{Conditionality and the EU legal framework: Open issues}

Despite the explicit provision in article 136 TFEU, the strict conditionality provided by the ESM still represents something of a black hole, prompting further questions. In this section, I will address some of the enduring issues concerning conditionality under the ESM.

First, the legal form of the ESM itself is examined, as it operates outside of the umbrella of EU law but within the realm of international law, which raises questions regarding its democratic nature and its accountability. The second issue concerns the legal nature and binding force of MoUs, which are still debated among legal scholars. ${ }^{25}$

\section{1 'Escape' from the Treaties}

One of the most debated issues of the anti-crisis mechanism was that they were instituted outside of the legal framework of the EU, but through the intergovernmental procedure, resulting in a sort of 'circumvention of Union law', and thereby a potential threat to European democracy and to the rule of law. ${ }^{26}$ That is, since the first rescue programme was set up for Greece, and adopted in the form of bilateral agreement by Member States, to the EFSF, EFSM and the ESM, a sort of 'escape' from EU law has taken place, through the use of public international law or private international law. ${ }^{27}$

Of course, the main reasons for this recourse to measures outside the EU legal framework were the extraordinary circumstances of the debt crisis, and the need for flexibility and a prompt response to such events that would not be possible to achieve following the EU decision-making procedures. ${ }^{28}$ Moreover, we have to acknowledge the likelihood that only Member States possessed the necessary fiscal means for rescue operations, not the Union. ${ }^{29}$ Lastly, according to many commentators, the solution that led to the establishment of the ESM was perhaps inevitable in light of the formulation of article 136 TFEU: 'The fact that the amendment indicated that the mechanism would be established "by the Member States whose currency is the euro", left no other choice than the use of an international agreement. ${ }^{\prime 30}$

However, we cannot ignore the consequences that such a choice had on the EU and national legal spheres. Critically, this intergovernmental approach signalled a step back

25 See Xenophon Contiades and Ioannis A Tassopoulos, 'The Impact of the Financial Crisis on the Greek Constitution' in Xenophon Contiades (ed), Constitutions in the Global Financial Crisis: A Comparative Analysis (Ashgate 2013) 202.

26 Jonathan Tomkin, 'Contradiction, Circumvention, and Conceptual Gymnastics: The Impact of the Adoption of the ESM Treaty on the State of European Democracy' (2013) 14 German LJ 169, 180.

27 On the different nature in the legal form of the mechanisms adopted, see Tuori and Tuori (n 11) 97.

28 See Edoardo Chiti and Pedro Gustavo Teixeira, 'The Constitutional Implications of the European Responses to the Financial and Public Debt Crisis' (2013) 50 CML Rev 683.

29 Tuori and Tuori (n 11) 123.

30 Bruno de Witte and Thomas Beukers, 'The Court of Justice Approves the Creation of the European Stability Mechanism outside the EU Legal Order: Pringle' (2013) 50 CML Rev 805, 812. 
from the efforts made through the Treaty of Lisbon to enforce the democratic principle and accountability at the EU level. While the Treaty stressed the role of democracy and enforced the powers of the European Parliament and of national parliaments, the response to the crisis determined an affirmation of a sort of executive federalism, 'which would provide the template for a post-democratic exercise of political authority', as Jürgen Habermas has argued. ${ }^{31}$

Within the ESM context, no powers have been given to the European Parliament. The latter, after examining the Draft of the European Council Decision on the establishment of the ESM, proposed some changes to article 136, providing in particular that the rules for conditionality of financial assistance should have been determined by an EU regulation adopted under co-decision. ${ }^{32}$ However, this proposal was discarded by the European Council, which provided only to strengthen the involvement of the European Commission in the operation of the ESM, thereby acting as an 'agent of the intergovernmental cooperation system. ${ }^{33}$

Additionally, not only does the ESM elude any kind of democratic accountability, but nor are its operations subject to the constraints of the EU legal system, such as, for example, the subsidiarity control. ${ }^{34}$ Another issue here concerns the applicability of the Charter of Fundamental Rights of the EU (Charter) to the EU institutions and to the Member States acting under the ESM. ${ }^{35}$ For instance, the Court of Justice in the Pringle case ruled that the Charter did not bind the Member States because, when they established a stability mechanism such as the ESM, they were not implementing EU law, since the Treaties 'do not confer any specific competence on the Union to establish such a mechanism. ${ }^{36}$

There is also some controversy in the application of the Charter to EU institutions acting in the context of the ESM - on this point, the Court of Justice was silent, leaving the issue open. ${ }^{37}$ Textual interpretation of article 51 of the Charter refers the limit of 'implementing Union law' only to Member States, making the EU institutions bound by the Charter whether they act within the scope of EU law or not, and therefore even when they act as an ESM 'agent'. However, such a conclusion prompts further questions. For example, when the Commission signs MoUs on behalf of the ESM, is it bound by the Charter? In Pringle, the Court of Justice seemed to exclude such a conclusion:

Jürgen Habermas, The Crisis of the European Union: A Response (Ciaran Cronin tr, Polity Press 2012) viii.

32 European Parliament Resolution of 23 March 2011 on the Draft European Council Decision amending Article 136 of the Treaty on the Functioning of the European Union with regard to a stability mechanism for Member States whose currency is the euro [2011] P7_TA(2011)0103.

33 de Witte (n 17) 812.

34 ibid 846.

35 Charter of Fundamental Rights of the European Union [2012] OJ C326/391.

36 Case C-370/12 Pringle (n 7) para 180.

37 Paul Craig, 'Pringle and Use of EU Institutions Outside the EU Legal Framework: Foundations, Procedure and Substance' (2013) 9 EuConst L Rev 263. See also Margot E Salomon, 'Of Austerity, Human Rights and International Institutions' (2015) 21 ELJ 521. 
[T] he duties conferred on the Commission and ECB within the ESM Treaty, important as they are, do not entail any power to make decisions of their own. Further, the activities pursued by those two institutions within the ESM Treaty solely commit the ESM. ${ }^{38}$

In other words, the fact that EU institutions within the ESM could not adopt binding decisions per se, but just on behalf of the ESM, seemed to render the question of the binding nature of the Charter superfluous in the eyes of the Court. ${ }^{39}$ However, a different narrative has been sustained by Andreas Fischer-Lescano, who affirmed that article 51 of the Charter applies to the EU institutions 'always and at all times', even when they undertake tasks under the ESM. ${ }^{40}$

As this uncertain situation regarding the Charter demonstrates, the use of international instruments by Member States and the involvement of EU institutions in international organisations creates a sort of 'free zone' in which guarantees accorded by the application of EU law are weakened and their legitimacy is contested.

\subsection{A corollary: The controversial nature of MoUs}

In this context, even the legal nature of MoUs is debatable and so deserves a brief reflection. Some scholars have argued that they constitute 'simplified agreements', in the sense of article V of the Articles of Agreement of the IMF, with no binding value nor restricting national sovereignty. ${ }^{41}$ According to this reasoning, they are just political programmes, containing programmatic provisions.

In contrast, others recognise MoUs as international law treaties having binding force. $^{42}$ This interpretation is based on International Court of Justice (ICJ) case law, which does not exclude an agreement not having the traditional form of a treaty from being considered as an international law treaty. ${ }^{43}$ The Portuguese Constitutional Court (Tribunal Constitucional) seems to agree with the latter view, having underlined the binding effect of MoUs in its Decision No 187/2013, which is further discussed below. ${ }^{44}$ Conversely, the Greek Council of State (the Supreme Administrative Court of Greece) denied the categorisation of international treaty to MoUs, designating them instead as political programmes, 'setting targets to be achieved and policies to be implemented in

38 Case C-370/12 Pringle (n 7) para 161.

39 Steve Peers, 'Towards a New Form of EU Law?: The Use of EU Institutions outside the EU Legal Framework' (2013) 9 EuConst L Rev 37. For a different view, see Salomon (n 37).

40 Andreas Fischer-Lescano, Human Rights in Times of Austerity Policy: The EU Institutions and the Conclusion of Memoranda of Understanding (Nomos 2014) 9.

41 See Afroditi Ioanna Marketou and Michail Dekastros, 'A Multi-Level Legal Analysis-Reports by Country-Greece' (Constitutional Change through Euro Crisis Law, 16 January 2014) <http://eurocrisislaw. eui.eu/greece/> accessed 15 April 2015; Articles of Agreement of the International Monetary Fund (adopted 22 July 1944, entered into force 21 December 1945) 2 UNTS 39, art V.

42 Jan Klabbers, The Concept of Treaty in International Law (Kluwer Law International 1996) 42.

43 Fischer-Lescano (n 40) 32, citing Case concerning Maritime Delimitation and Territorial Questions between Qatar and Bahrain (Qatar v Bahrain) (Jurisdiction and Admissibility) [1994] ICJ Rep 7, 112.

44 Portuguese Constitutional Court Decision No 187/2013 of 5 April 2013. 
due time. ${ }^{45}$ Finally, other scholars consider MoUs as sui generis acts, not being formally international treaties but having binding effects. ${ }^{46}$

The unresolved issue of the nature of MoUs also impacts on their status within EU law and, in particular, on the question of whether or not they represent an implementation of EU law, and therefore if they are justiciable in the light of the Charter. According to CJEU case law, MoUs do not constitute an implementation of EU law. The Court ruled in that sense in Case C-128/12 Sindicato dos Bancários do Norte and Others, where it affirmed that it had no jurisdiction in evaluating the conformity of the national implementation law of the MoU with the Charter. ${ }^{47}$ However, this conclusion of the Court of Justice is contested in the literature. In particular, it has been affirmed that 'MoUs do constitute an implementation of EU law. ${ }^{48}$ This assessment

is more prevalent since EU Regulation 472/2013 entered into force on 30 May 2013, which reinforces the link between EU law and financial aid awarded upon the basis of international law. Article 7(1) obliges the EU Member States that request or receive financial assistance to present a macroeconomic adjustment programme that 'shall fully observe' Art 28 [of the Charter ${ }^{49}$

This provision applies to Member States that, on 30 May 2013, received financial assistance, and therefore it concerns Ireland, Portugal, Greece, and Cyprus.

\section{Impacts of conditionality: Challenges and contradictions}

Even under a substantial point of view, conditionality measures are highly contested. The first issue that will be addressed in this section concerns the content of MoUs signed under the ESM and providing the conditions of financial assistance. The latter range from financial measures to macroeconomic decisions that correspondingly affect fundamental social rights of the beneficiary States, in turn raising questions concerning a trade-off between human rights and financial stability.

Secondly, I address the democratic deficit of the ESM as seen from a national perspective and, in particular, by the marginal role reserved to national parliaments in the definition and in the acceptance of the conditions imposed through a $\mathrm{MoU}$ and signed by the benefitting government.

45 Contiades and Tassopoulos (n 25) 203.

46 Fischer-Lescano (n 40) 32.

47 Case C-128/12 Sindicato dos Bancários do Norte and Others v BPN-Banco Português de Negócios, SA [2013] EU:C:2013:149, paras 10-14. See also Case C-434/11 Corpul Național al Polițiştilor v Ministerul Administrației şi Internelor (MAI) and Others [2011] EU:C:2011:830.

48 Florian Rödl and Raphael Callsen, 'The Struggle for Union Rights under the Euro and the Dialectics of Social Integration' in Christian Joerges and Carolina Glinski (eds), The European Crisis and the Transformation of Transnational Governance: Authoritarian Managerialism versus Democratic Governance (Hart Publishing 2014) 117.

49 ibid. 


\subsection{Conditionality and the 'human rights trade-off'}

Moving from a formal to a substantial approach regarding strict conditionality and MoUs, the scenario is even more complex, and perplexing questions remain unresolved.

It is generally agreed that austerity measures have had an extensive impact in the field of social rights, such as in health care, social protection and education-areas that, as expressed by the Federal Constitutional Court of Germany (Bundesverfassungsgericht) in the Treaty of Lisbon (Lissabon Urteil), pertain to the core of national sovereignty. ${ }^{50}$ Furthermore, this impact has often resulted in an encroachment of fundamental rights. ${ }^{51}$ To consider this issue in more detail, I will analyse the MoUs negotiated by the Troika (the IMF, EU and ECB) and signed by Greece, ${ }^{52}$ Portugal, ${ }^{53}$ and Ireland. ${ }^{54}$

A common area of intervention of MoUs is that of labour law-probably one of the areas most affected by conditionality. In the case of Greece, its conditionality measures prescribed, among other things, a reduction of the highest pensions and a reduction of the Easter, Summer and Christmas bonuses and allowances paid to civil servants. ${ }^{55}$ In Ireland, the MoU laid down an obligation for a reduction in the minimum wage level and, in Portugal, a reduction of unemployment insurance benefits. ${ }^{56}$

Even health and education rights have been affected by the conditionality provisions: the MoUs for Greece required a reduction in pharmaceutical expenditure, cuts in health care services, and the implementation of a comprehensive reform of the health care system. ${ }^{57}$ Obligations affecting the right to education provided for a reduction of costs and for a more efficient use of resources. ${ }^{58}$ In Ireland, the MoU prescribed an increase in student contributions toward tertiary education. ${ }^{59}$ It has been argued that the conditions settled by the MoUs imposed a 'welfare state retrenchment unprecedented

50 Germany's Federal Constitutional Court Judgment, 2 BvE 2/08 (2009).

51 Fischer-Lescano (n 40) 32.

52 European Commission, 'The Second Economic Adjustment Programme for Greece-Fourth Review' (2014) European Economy Occasional Papers 192, 181 <http://www.efsf.europa.eu/attachments/ocp192_ en.pdf $>$ accessed 12 September 2015.

53 'Portugal: Memorandum of Understanding on Specific Economic Policy Conditionality' (17 May 2011) (Portugal MoU) <http://ec.europa.eu/economy_finance/eu_borrower/mou/2011-05-18-mou-portugal_ en.pdf $>$ accessed 10 April 2015.

54 'Ireland: Memorandum of Understanding on Specific Economic Policy Conditionality' (3 December 2010) (Ireland MoU) <http://ec.europa.eu/economy_finance/articles/eu_economic_situation/pdf/2010-12-07mou_en.pdf $>$ accessed 10 April 2015.

55 European Commission, 'Second Economic Adjustment Programme for Greece' (n 52) 47-50.

56 Ireland MoU (n 54) 5; Portugal MoU (n 53) 21.

57 European Commission, 'Second Economic Adjustment Programme for Greece' (n 52) 39-43.

58 ibid 44-45.

59 Aoife Nolan, 'Welfare Rights in Crisis in the Eurozone: Ireland' in Claire Kilpatrick and Bruno de Witte (eds), Social Rights in Times of Crisis in the Eurozone: The Role of Fundamental Rights' Challenges (2014) European University Institute LAW Working Paper 2014/05, 30, 33-35 <http://cadmus.eui.eu/ bitstream/handle/1814/31247/LAW\%20WP\%202014\%2005\%20Social\%20Rights\%20final\%202242014. pdf? sequence $=1>$ accessed 22 December 2015. 
in the post-war period. ${ }^{60}$ Furthermore, conditionality also included a massive process of privatisation of public sector operations (such as water, electricity and transportation services and companies). ${ }^{61}$

Prominent legal scholars have addressed this level of austerity measures as a violation of fundamental principles entrenched in national constitutions. ${ }^{62}$ Referring to the Greek case, Katrougalos observed that the above-mentioned measures violated structural constitutional principles, such as the principle of equality and fundamental social rights (as provided by articles 21, 22 and 23 of the Greek Constitution). ${ }^{63}$ Recently, the supreme courts of Greece and Portugal ruled against the compatibility of such measures with their respective constitutions arising in such a way as the bastions of national democracy and of human rights. Even at the supranational level, these austerity measures have attracted doubts concerning their compatibility with the provisions of the Charter and with the European Social Charter. ${ }^{64}$ The European Committee of Social Rights condemned Greece for violation of articles 10 and 12 of the European Social Charter because of its austerity legislation enacted in $2010 .{ }^{65}$

Last but not least, we cannot ignore the popular perception of such measures. The recent result of the political election in Greece as well as the protests in Athens, Madrid and Lisbon indicate that citizens 'experience a rigid dis-embedding of their markets and cannot believe that austerity will lead to sustainable societal reform. ${ }^{66}$ The negative impact of the austerity measures, the widespread discontent across both debtor and creditor countries, and the encroachment of fundamental rights all suggest a need to 'complement austerity with ideas to strengthen the social dimension of the EMU' and the human rights side of the EU-to date, a 'road not taken' ${ }^{67}$

\subsection{Conditionality and the democratic trade-off: Parliaments as 'side players'}

In addition to the human rights issue, the other major objection to regimes of strict conditionality is a democratic concern-specifically, the marginalisation of parliaments in the decision-making process that led to the negotiation of the MoUs and in the

60 Aristea Koukiadaki and Lefteris Kretsos, 'Opening Pandora's Box: The Sovereign Debt Crisis and Labour Market Regulation in Greece’ (2013) 41 Industrial LJ 276, 277.

61 European Commission, 'Second Economic Adjustment Programme for Greece' (n 52) 26-29; Ireland MoU (n 54) 10; Portugal MoU (n 53) 13-14.

62 Salomon (n 37) 532-35.

63 George Katrougalos, 'The Greek Austerity Measures: Violations of Socio-Economic Rights' (Intl J Const L Blog, 29 January 2013) <www.iconnectblog.com/2013/01/the-greek-austerity-measures-violations-ofsocio-economic-rights> accessed 10 April 2015.

64 Revised European Social Charter (adopted 3 May 1996, entered into force 1 July 1999) 2151 UNTS 277.

65 Federation of employed pensioners of Greece (IKA-ETAM) v Greece (Complaint) European Committee of Social Rights No 76 (16 January 2012).

66 Joerges (n 1) 43.

67 ibid. See also Gráinne de Búrca, 'The Road Not Taken: The European Union as a Global Human Rights Actor' (2011) 105 AJIL 649. 
scrutiny of the conditions of financial assistance. As Ioannidis advises, in the context of EU financial assistance, three different categories of parliaments can be distinguished: the European Parliament, the national parliaments of the creditor countries and the national parliaments of the assisted countries. ${ }^{68}$ Regarding the European Parliament, the procedure to accord financial assistance within the framework of the ESM did not reserve much space for parliamentary control. As noted above, according to article 13 of the ESM Treaty, the European Commission-in liaison with the ECB and, wherever possible, together with the IMF-is entrusted with the task of negotiating, with the ESM Member State concerned, a MoU detailing the conditionality attached to the financial assistance facility. Following the approval of the Board of Governors, the European Commission signs the MoU on behalf of the ESM, and the Board of Directors approves the financial assistance facility agreement detailing the financial aspects of the stability support to be granted. ${ }^{69}$ Note, too, that the European Commission-in liaison with the ECB and the IMF-is entrusted with monitoring compliance with the conditionality attached to the financial assistance facility. ${ }^{70}$ Thus, the pivotal role is exerted, on one side, by the executive branch (Board of Governors, EU Commission) and, on the other, by the technocratic branch (Board of Directors, IMF, ECB) of the ESM.

Regulation 472/2013 introduced some negligible procedures regarding the involvement of the European Parliament, in particular in the area of the exchange of information and views. Article 7 of the Regulation provides that, in the case of a Member State requesting financial assistance, the ESM authorities have to draft a macroeconomic adjustment programme, and the Commission orally informs the Chair and Vice-Chairs of the competent committee of the European Parliament of the progress made in the preparation of the draft macroeconomic adjustment programme. ${ }^{71}$ Moreover, the competent committee of the European Parliament may offer the opportunity to the Member State concerned and to the Commission to participate in an exchange of views on the progress made in the implementation of the macroeconomic adjustment programme. ${ }^{72}$ However, even if the provisions of Regulation 472/2013 represent a breach into the executive-dominated procedures, the role of the European Parliament is confined to the exchange of information, which has nothing to do with the exercise of parliamentary control and accountability. Neither do the provisions of this Regulation carve out a role for the European Parliament in the decision-making process. As Ioannidis has pointed out, a situation of accountability would require not only duties of information, but also the possibility for the European Parliament to impose sanctions if not satisfied with the information and justification given. ${ }^{73}$

\footnotetext{
68 Ioannidis (n 24) 100.

69 Art 13 ESM Treaty.

70 ibid.

71 Art 7(4) Regulation 472/2013.

72 Art 7(10) Regulation 472/2013.

73 Ioannidis (n 24) 103.
} 
With regard to national parliaments, their power varies in different Member States, and in particular in creditor and debtor countries. While in the former (namely Germany, France, and Austria) national parliaments have strengthened their control powers and their participation in economic and financial matters, in the latter (Greece, Portugal, and Spain in particular) parliaments had to comply with austerity programmes and with the rules set up at the European level. ${ }^{74}$ In recipient countries, therefore, national parliaments remain in the penumbra of the decision-making process on financial programmes and on conditionality. Negotiations of conditions are undertaken by governments, with parliaments confined to the role of ratification of the decision taken in other fora, without the chance to assure democratic accountability control on their respective governments.

However, even the role of national parliaments in the transposition of MoUs and other financial agreements into the national legal orders depends on the recognised value of the international agreement and on specific constitutional provisions in each Member State. For example, in Ireland, MoUs are not international agreements, and therefore they do not require authorisation by the national parliament. ${ }^{75}$ In Portugal, on the other hand, the question was seriously debated, as the nature of MoUs was considered to be controversial. The MoU was approved by the government, without any parliamentary contribution. However, it has been argued that, 'as the obligations included in the MoU fall into Parliament competences, it should have been actually approved by the Parliament.' ${ }^{76}$ The Portuguese parliament has played, though, a fundamental role in discussing and approving, or not approving, bills that implement measures agreed in its MoU. Different again and much more troubled has been the solution adopted by Greece. As already mentioned, there has been great national debate about the nature of MoUs. In particular, the issue was debated in parliament during the approval of Law 3845/2010. ${ }^{77}$ At the time of the first rescue programme, MoUs had been recognised as part of the nature of the political programme, and therefore not requiring parliamentary approval. MoUs were, however, annexed to Law 3845/2010, which was approved by the Greek parliament on 6 May 2010. It has been asserted that the Greek parliament, by voting on Law 3845/2010,

sanctioned from the point of view of the domestic legal order the various acts through which political actors (other than the Greek state) cooperating in the Greek bailout had tried to

74 Arthur Benz, 'An Asymmetric Two-level Game: Parliaments in the Euro Crisis' in Ben Crum and John Erik Fossum (eds), Practices of Interparliamentary Coordination in International Politics: The European Union and Beyond (ECPR Press 2013) 135-37.

75 Darren O'Donovan, 'IMF Conditionality, the Irish Constitution and the Need for a Dáil Vote on the Bailout Agreement' (Human Rights in Ireland, 22 November 2010) <http://humanrights.ie/constitution-of-ireland/ imf-conditionality-the-irish-constitution-and-the-need-for-a-dail-vote-on-the-bailout-agreement/> accessed 21 November 2015.

76 See Rita de Brito Gião Hanek and Daniele Gallo, 'A Multi-Level Legal Analysis-Reports by CountryPortugal' (Constitutional Change through Euro Crisis Law, 2 February 2015) <http://eurocrisislaw.eui.eu/ portugal/> accessed 4 July 2015.

77 Law 3845/2010 of 6 May 2010, Government Gazette A 65 (Greece). 
invest in the appropriate legal form and to ground their political decisions as provided in the basic legal instrument (treaties, charters and so forth) out of which they derived their authority. $^{78}$

However, the procedure adopted for the second rescue programme, which was considered to be a simplified agreement, was different. The Greek parliament passed Law 4046/2012 regarding the approval of the new Loan Agreement with the IMF on 12 February 2012, before the signature of the MoUs by the government. In this way, the country's parliament approved the acts of the financial assistance and delegated their signature to the Minister of Finance.

Overall, Regulation 472/2013 has introduced limited prerogatives for national parliaments, in the form of information rights-but even weaker privileges were reserved for the European Parliament. Certainly, according to the domestic rules of procedures, national parliaments are not prevented from exercising their legislative powers when called to adopt the national measures necessary to implement the conditions established in the MoUs and in bailout programmes. However, the power of a national parliament to refuse to implement the programmes signed by its government remains only written on paper. Moreover, the conditions of assistance programmes have already been decided by the Troika and the executive: national parliaments have just to accept the deal or maybe 'draw some broad red lines of accepted policies rather than making concrete decisions. ${ }^{79}$

National parliaments are forced to accept the conditions settled in bailout programmes, since they are under a sword of Damocles with respect to the possibility of losing economic assistance. This marginalisation of national parliaments is in conflict with the spirit of the Treaty of Lisbon, which positions democracy at the heart of the EU, providing for the enhancement of the role of national parliaments, both through political dialogue and the 'early warning system' mechanism. ${ }^{80}$ The sui generis nature of MoUs and of the related agreements, which cannot be subject to subsidiarity controls as they are not acts of the EU institutions, has weakened the role of national parliaments in the EU space, which they had earlier gained after being appointed for years the 'losers of integration. ${ }^{\text {,1 }}$ Moreover, as Arthur Benz argued, 'the crisis further weakened national parliaments in some of those Member States which, according to research findings, had been assessed as comparatively weak in any case. ${ }^{82}$ Identifying this democratic concern confirms what has already emerged through analysing the human rights issue: the legislation of the debt crisis and, in particular, the conditionality regime represent a sort of 'enclave' within the EU legal framework, in which the basic commitments of the EU

78 Contiades and Tassopoulos (n 25) 199-200.

79 Ioannidis (n 24) 103.

80 Arts 2, 4, 12 TEU.

81 As Habermas observes, national parliaments 'cannot avoid the suspicion of merely rubber-stamping prior decisions taken elsewhere-that is, merely reproducing them in a more concrete form. This suspicion inevitably corrodes any democratic credibility': Habermas (n 31) 130.

82 Benz (n 74) 137. 
as a constitutional project, above all democracy and human rights protection, seem to have been broken up.

\section{Role of the national judiciary: The case of the Portuguese Constitutional Court}

Conditionality measures and austerity policies suffer, as has been demonstrated above, from a democratic deficit: they are negotiated by supranational authorities, whose nature is executive or technical, and by national governments. The legislatures, both at national and at EU level, are excluded from the decision-making process and, even when there is a kind of involvement, it is either limited to informative duties or it lacks effectiveness. In addition, austerity measures and their national implementation affect fundamental rights and social rights of citizens.

In this scenario, in which traditional democratic circuits have been circumvented, constitutional courts would seem to offer a crucial role in protecting fundamental rights enshrined in national constitutions that were violated by some of the legislation enacted to face the debt crisis. ${ }^{83}$ However, the price of the activism of a national judiciary in striking down legislation implementing international financial commitments might be high, both in financial and in political terms. This is why, at least at the very beginning of the assistance programmes, national courts adopted a cautious approach in assessing the constitutionality of the austerity measures. The Greek crisis case law, for example, shows a very deferential attitude towards the decisions taken to implement the conditions of the MoUs: the Greek Council of State in Decisions No 668/2012 and No 1685/2013 upheld the measures prescribed in the first Memorandum, grounding its ruling on the state of exception and on the need to enhance the financial credibility of Greece, with respect to the commitments assumed with the Troika. ${ }^{84}$

Emblematic of this dilemma is the approach that the Portuguese Constitutional Court, the most active constitutional court in dealing with debt crisis legislation, adopted towards the austerity measures introduced in the country on the impulse of the Troika, with particular reference to social rights protection. As Cristina Fasone has recorded, in the constitutional case law dealing with the Eurozone crisis, the Portuguese Constitutional Court gradually abandoned the deferential approach towards the legislator and, having issued warnings to the government and to the parliament, finally 'dropped the bomb' in

83 For a comparative overview, see Cristina Fasone, 'Constitutional Courts Facing the Euro Crisis: Italy, Portugal and Spain in a Comparative Perspective' (2014) European University Institute Working Paper MWP 2014/25 <http://cadmus.eui.eu/bitstream/handle/1814/33859/MWP_WP_2014_25.pdf > accessed 4 July 2015.

84 See Christina M Akrivopoulou, 'Facing l'Etat d'Exception: The Greek Crisis Jurisprudence' (Intl J Const L Blog, 11 July 2013) <www.iconnectblog.com/2013/07/facing-letat-dexception-the-greek-crisisjurisprudence/> accessed 30 June 2015 . 
2013 with Decision No 187/2013, in which the Court struck down the pay and pension cuts for public employees. ${ }^{85}$

In the very first decision concerning the crisis legislation, the Portuguese Constitutional Court maintained the traditional self-restraint, upholding the provisions of the State Budget Law for 2011 on the cutback of public salaries. ${ }^{86}$ In this case, the Court dismissed the challenges to the Budget Law, ruling that there was no violation of the principle of equality, the principle of protection of legitimate expectations, or the principle of proportionality. According to the Court, the transitional nature of the measures challenged, due to the 'conjuntura de absoluta excepcionalidade' (absolutely exceptional context), justified the cuts to public salaries.

However, a few months later, the position of the Court moved from this traditionally deferential approach to parliament to a challenging one: in its Decision No 353/2012, the Court declared several provisions of the State Budget Law for 2012 unconstitutional. ${ }^{87}$ In particular, according to the Court, the norms providing for the suspension of Christmas and holiday-month payments during 2012-14 for public sector workers and retirees were unconstitutional because they violated the principle of equality, requiring the just distribution of public costs between all citizens in proportion to each one's financial capacity. This decision is interesting from a couple of different points of view. The first one to be underlined is the fact that, even while declaring the proposed provisions unconstitutional, the Court restricted the temporal effects of the declaration of unconstitutionality, ruling that it did not apply to the suspension of payment of Christmas and holiday bonuses with respect to 2012. The Court assessed that, since the execution of the 2012 Budget was already well underway, the consequences of an unqualified declaration of unconstitutionality could endanger the maintenance of the agreed financing, and thus the state's solvency. ${ }^{88}$ The second remarkable aspect of this decision is the fact that the Court defined, for the first time, that the MoUs on the basis of which the contested measures had been adopted were binding instruments of international law and EU law. However, this did not prevent the Court from affirming that:

[T] he extremely serious economic/financial situation and the need for the measures that are adopted to deal with it to be effective cannot serve as grounds for dispensing the legislator from being subject to the fundamental rights and key structural principles of the state based on the rule of law, and this is true namely with regard to parameters such as the principle of proportional equality. ${ }^{89}$

85 Fasone (n 83) 24. Portuguese Constitutional Court Decision No 187/2013 (n 44).

86 Portuguese Constitutional Court Decision No 396/2011 of 21 September 2011; State Budget Law No 55A/2010 of 31 December 2010 (Portugal).

87 Portuguese Constitutional Court Decision No 353/2012 of 5 July 2012 <http://www.tribunalconstitucional. pt/tc/acordaos/20120353.html > accessed 17 November 2015. State Budget Law No 64-B/2011 of 30 December 2011 (Portugal).

88 ibid.

89 ibid. 
A decisive aspect in the Court's overturning of its precedents was the fact that the cuts to remunerations and pensions lost their original 'extraordinary and provisional' nature due to the emergence of the economic crisis, and instead seemed destined to endure for years, with terrible and persistent consequences for the levels of remuneration for the specified categories of workers. ${ }^{90}$

After this 'warning', the Portuguese Constitutional Court, in subsequent case law, adopted a progressively more 'activist' approach. The foremost case of this period of jurisprudence was the above-mentioned Decision No 187/2013. ${ }^{91}$ The Court declared as unconstitutional several provisions of the Budget Law for 2013, namely, the suspension of the additional holiday month of salary for public administration staff (and also for teachers and researchers), the suspension of the holiday month of pensions for public and private sector retirees, and the duty imposed upon the beneficiaries of unemployment subsidies to pay social security contributions of 6 per cent instead of 5 per cent, in violation of the principles of equality and proportionality. ${ }^{92}$ Thus, it was argued:

[T] he Portuguese jurisprudence represents a judicial response to austerity measures. (...) In this way, the [Portuguese Constitutional Court], relying on the principle of equality (and on its corollaries), seems to have urged the legislator to better exercise the competences and powers it seems to have given up in favour of international and European constraints. ${ }^{93}$

Furthermore:

[S] uch decisions can be paradoxically regarded as aimed at protecting the national legislator, by giving back to it the power to decide on some critical issues, under, evidently, the guidance provided by the [Portuguese Constitutional Court] as regards the respect of fundamental rights under the national Constitution. ${ }^{94}$

However, this decision to strike down some of the austerity measures taken based on the MoUs produced divisions both in the national political situation and in the relationship between Portugal and the Troika, as was perhaps inevitable. Regarding the former, the Prime Minister, following the decision of the Constitutional Court, threatened to resign and, later on, the Minister for Parliamentary Affairs and the Minister of Finance both left their respective posts. As for Portuguese relations with the Troika and the EU, Portugal had to renegotiate the conditions of its financial assistance programme. In particular, during the seventh update of its MoU, a point on 'legal safeguards' was added, explicitly stating

90 ibid.

91 Portuguese Constitutional Court Decision No 187/2013 (n 44); State Budget Law No 66-B/2012 of 31 December 2012 (Portugal).

92 Portuguese Constitutional Court Decision No 187/2013 (n 44).

93 Roberto Cisotta and Daniele Gallo, 'The Portuguese Constitutional Court Case Law on Austerity Measures: A Reappraisal' in Claire Kilpatrick and Bruno de Witte (eds), Social Rights in Times of Crisis in the Eurozone: The Role of Fundamental Rights' Challenges (2014) European University Institute LAW Working Paper 2014/05, 92-93 <http://cadmus.eui.eu/bitstream/handle/1814/31247/LAW\%20WP\%20 2014\%2005\%20Social\%20Rights\%20final\%202242014.pdf?sequence=1> accessed 30 June 2015 .

94 ibid 91. 
that the Portuguese authorities 'will take a number of steps aimed at mitigating legal risks from future potential Constitutional Court rulings. ${ }^{95}$ However, the Constitutional Court went on to follow, in subsequent rulings, the trend it had established with Decision No 187/2013. In Decisions No 602/2013, No 862/2013, No 413/2014 and No 575/2014, the Court once more struck down provisions concerning labour law (for example, legislative measures that would make it easier for the government to dismiss civil servants, cuts in public wages) and the public pension system's reform, thereby affecting its relation with the government and the legislature. ${ }^{96}$

It can be argued that the reaction of the Portuguese Constitutional Court to the austerity measures set to comply with international agreements is emblematic of the new challenges that economic governance poses to national democracy. It may well be 'quite natural for a Constitutional Court to evaluate the reasonableness-in terms of proportionality, as well as of their suitability to achieve the prefixed goals-of measures adopted by a government, also if previously agreed on the international plane, ${ }^{97}$ but we cannot help but notice that the struggle engaged in by the Portuguese Constitutional Court had an effect both on the balance of powers in the domestic domain, reshaping the relations between the government and parliament, as well as on the supranational level, requiring ongoing negotiations of conditions among the actors involved, determining in this way a sort of 'short circuit' of legitimation.

\section{Conclusions}

This article has endeavoured to shed light on the 'black holes' that the adoption of the instrument of conditionality within the EMU implies, both at national and at EU levels.

95 In particular, the following 'legal safeguards' were added:

First, expenditure reforms will be designed with the principle of public/private sector and intergenerational equity in mind as well as the need to address the sustainability of social security systems. Second, legislation underpinning the expenditure reforms will be duly justified on compliance with the fiscal sustainability rules in the recently ratified European Fiscal Compact which now ranks higher than ordinary legislation. Third, the government will rely as much as possible on general laws rather than on one-year budget laws consistent with the structural nature of the reforms. This also opens the possibility of prior constitutional review of said laws, thus allowing early reaction on the part of the government in case these reforms raise constitutional issues.

IMF, 'Portugal: Letter of Intent, Memorandum of Economic and Financial Policies, and Technical Memorandum of Understanding' (12 June 2013) <www.imf.org/external/np/loi/2013/prt/061213.pdf> accessed 7 July 2015. See also Miguel Nogueira de Brito, 'Putting Social Rights in Brackets? The Portuguese Experience with Welfare Challenges in Times of Crisis' in Claire Kilpatrick and Bruno de Witte (eds), Social Rights in Times of Crisis in the Eurozone: The Role of Fundamental Rights' Challenges (2014) European University Institute LAW Working Paper 2014/05, 70 <http://cadmus.eui.eu/bitstream/handle/1814/31247/ LAW\%20WP\%202014\%2005\%20Social\%20Rights\%20final\%202242014.pdf? sequence=1> accessed 30 June 2015.

96 Portuguese Constitutional Court Decisions: No 602/2013 of 20 September 2013; No 862/2013 of 19 December 2013; No 413/2014 of 30 May 2014; No 575/2014 of 14 August 2014.

97 Cisotta and Gallo (n 93) 91 (emphasis in original). 
They represent controversial instruments, as well as an expression of a new model of economic governance raised by the incapacity of the EU institutions to react to the debt crisis and justified by the attending state of emergency.

The legitimacy of such conditionality measures, adopted through the framework of international law, as well as their legally binding nature, are the subject of much debate. What is certain is that they represent an exercise of authoritarian power 'neither based upon democratic process, nor upon an exchange of reasons among equals. ${ }^{98}$ They represent an enclave of international law within the EU legal framework, where the core principles of the EU project can be derogated by reason of a state of emergency determined by the debt crisis and the risk of default of some Member States. The result has been a step backwards to a model of intergovernmental relationships based on a clear asymmetry between debtor and creditor Member States, where it is the creditor states that call the shots, leaving the debtors the simple choice of compliance or exit. ${ }^{99}$

Instead of moving toward an ever-closer Union, this approach to managing the debt crisis has unveiled the weakness of the EU, in terms of political and fiscal powers, previously hidden, on the one hand, by the realisation of the monetary union and, on the other hand, by the narrative of the EU as a fundamental rights organisation, developed after the entry into force of the Charter. In other words, the Eurozone crisis has shed light on the unresolved compromises upon which the EU has been developed, reflecting 'the different perspectives on the Union that have accompanied the latter's institutionalization as a political system. ${ }^{100}$ In particular, the constraints imposed by the MoUs over basic social rights enshrined in national constitutions have revealed the need for a European social model, as well as highlighting a 'lack of a Union-level monitoring mechanism and (...) the non-existent commitment of key Union institutions. ${ }^{101}$

Moreover, the democratic trade-off brought about by the conditionality measures can be seen as a synecdoche for the democratic crisis of the EU as a whole. The marginal role of parliaments, with particular reference to the European Parliament, is a symbol of the democratic disconnect of the EU, stressed by the debt crisis management. Moreover, the lack of accountability that characterised decisions taken by the Troika cast shadows over the democratic principle at the EU level, and stressed what has been defined as the model of executive federalism. ${ }^{102}$

In sum, Europe's debt crisis management has highlighted the paradoxes and the compromises upon which the EU legal framework has been built. Whichever model ultimately prevails, the contentious nature of past approaches may suggest its future

\footnotetext{
98 Joerges (n 1) 34.

99 Ben Crum, 'Saving the Euro at the Cost of Democracy?' (2013) 51 JCMS 614, 622.

100 Sergio Fabbrini, Which European Union? (CUP 2015) xvii.

101 Tuori and Tuori (n 11) 241.

102 Habermas (n 31) 6. See also Federico Fabbrini, 'From Executive Federalism to Executive Government: Current Problems and Future Prospects in the Governance of EMU' in Federico Fabbrini, Ernst H Ballin and Han Somsen (eds), What Form of Government for the European Union and the Eurozone? (Hart Publishing 2015).
} 
direction: 'Rights must be complemented by political empowerment and civic solidarity for the Union to be able to develop a genuinely legitimate form of economic and political governance.' ${ }^{\text {103 }}$

103 Miguel Poiares Maduro, 'A New Governance for the European Union and the Euro: Democracy and Justice' (2012) European University Institute RSCAS PP 2012/11, $1<$ http://cadmus.eui.eu/bitstream/ handle/1814/24295/RSCAS_PP_2012_11rev.pdf?sequence=1> accessed 7 June 2015. 